\title{
Carney complex: an update
}

\section{Ricardo Correa, Paraskevi Salpea and Constantine A Stratakis}

Section on Endocrinology and Genetics, Program on Developmental Endocrinology and Genetics, Eunice Kennedy Shriver National Institute of Child Health and Human Development, National Institutes of Health, 10 Center Drive, Building 10, NIH-Clinical Research Center, Room 1-3330, MSC1103, Bethesda, Maryland 20892, USA

Correspondence should be addressed to C A Stratakis

Email

stratakc@mail.nih.gov

\section{Abstract}

Carney complex (CNC) is a rare autosomal dominant syndrome, characterized by pigmented lesions of the skin and mucosa, cardiac, cutaneous and other myxomas and multiple endocrine tumors. The disease is caused by inactivating mutations or large deletions of the PRKAR1A gene located at 17q22-24 coding for the regulatory subunit type I alpha of protein kinase $A$ (PKA) gene. Most recently, components of the complex have been associated with defects of other PKA subunits, such as the catalytic subunits PRKACA (adrenal hyperplasia) and PRKACB (pigmented spots, myxomas, pituitary adenomas). In this report, we review CNC, its clinical features, diagnosis, treatment and molecular etiology, including PRKAR1A mutations and the newest on PRKACA and PRKACB defects especially as they pertain to adrenal tumors and Cushing's syndrome.

\section{Introduction}

Carney complex (CNC) is a rare multiple neoplasia syndrome, inherited in an autosomal-dominant manner or occurring sporadically as a result of a de novo genetic defect. It is characterized by pigmented lesions of the skin and mucosae, cardiac, cutaneous and other myxomatous tumors, and multiple other endocrine and non-endocrine neoplasms $(1,2)$. It was first described by J Aidan Carney as 'the complex of myxomas, spotting pigmentation and endocrine over-reactivity' $(3,4)$. It was designated as CNC by Bain (5) and in 1994 as Carney syndrome by Mendelian Inheritance in Man (6).

More than half of the cases are familial $(2,7)$. Most of the patients who in the past had been diagnosed with lentigines, atrial myxomas, myxoid neurofibromas and ephelide or nevi, atrial myxoma, blue nevi should be reclassified today as $\mathrm{CNC}(1,3,8,9)$. CNC is in essence a multiple endocrine neoplasia syndrome, but one that affects a number of other tissues (10). This unique condition has similarities to other syndromes/diseases, such as the McCune-Albright, Peutz-Jeghers, Cowden, Bannayan-Zonana and Birt-Hogg-Dube syndromes, neurofibromatosis and other phacomatoses and hamartomatoses (10).

\section{Epidemiology}

CNC is a rare disease (4) with an unknown prevalence $(11,12)$. In the largest genotyped series of patients, $63 \%$ were females and 37\% were males (12). The NIH-Mayo clinic, and other centers in the USA and the Cochin Hospital in France, have collectively reported more than 750 cases including Caucasians, African-Americans and Asians from three continents (North and South America, Europe, Asia (Japan, China, India)) $(2,11,13)$. Approximately $70 \%$ of

\section{Invited Author's profile}

Constantine A Stratakis is the scientific director of NICHD, one of the largest institutes of the NIH. He is the recipient of the 1999 Endocrine Society Award for Excellence in Published Clinical Research and the 2009 Ernst Oppenheimer Award, and many others. He holds professorships in leading international academic centers. Dr Stratakis is a leading authority in the genetics of endocrine disorders and his laboratory has identified the genetics defects responsible for a number of diseases.

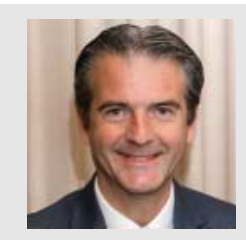

(C) 2015 European Society of Endocrinology Printed in Great Britain Published by Bioscientifica Ltd.
This article is adapted from work presented at IMPROCUSH-1, 12-14 October 2014. The meeting was supported by the European Science Foundation, Deutsche

Forschungsgemeinschaft, Carl Friedrich von Siemens Stiftung, European Neuroendo-

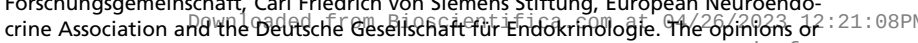
views expressed in this article are those of the authors, and do not necessarily reflecte access

the opinions or recommendations of the supporters of the symposium. 
CNC cases had an affected parent (67 families), whereas the remaining had no known affected relatives and carried de novo germline mutations (2). In all inherited cases, CNC was passed on as an autosomal-dominant trait with an almost $100 \%$ penetrance.

\section{Clinical features}

The clinical manifestations of $\mathrm{CNC}$ are quite variable and the full spectrum of the disease develops usually over a span of many years. Although the diagnosis is rarely made at birth, cases diagnosed as early as in the second year of life and as late as in the fifth decade of life are known with a median age at detection of 20 years old $(2,13)$. Table 1 summarizes all the clinical manifestations found in CNC patients.

\section{Cutaneous manifestations}

Skin lesions are the most definitive indication of CNC (1) and more than $80 \%$ of the patients report pigmented spots or skin 'growths' that are easily recognizable typically early in life. They can vary from lentigines and blue nevi (in particular epithelioid blue nevi, small bluish domed papules with a smooth surface) (14) to cutaneous myxomas. Café-au-lait spots, irregular depigmented areas, many compound and, rarely, Spitz nevi have also been reported $(12,15,16,17)$.

Lentigines (flat small brown to black macules) usually appear before puberty, increase in number and pigment intensity during and after adolescence. They may be located everywhere on the body but a rather typical distribution exists on the face, the lips, genital area and mucosa (Fig. 1A, B, C, and D). Although fading is common in old age, they can still be seen even in the very elderly $(8,18,19,20)$. African Americans may manifest with slightly raised dark papules $(21,22)$.

Epithelioid blue nevus (EBN) is an interesting subtype of blue nevus that is very rare in the general population, but is relatively commonly seen in patients with CNC. EBN presents with intensive pigmentation and poorly circumscribed proliferative regions with associated dermal fibrosis $(16,23)$. EBN is not pathognomonic for CNC but is frequently associated with the disease, and its presence should alert the clinician to the possible diagnosis of the complex (15).

Cutaneous myxomas (Fig. 1D, E, and F) are found in $30-55 \%$ of CNC patients and usually appear in the eyelid, external ear canal, nipples and the genitalia $(12,15)$. These lesion can be localized in the dermis or the subcutaneous
Table 1 Summary of clinical manifestations of CNC.

\begin{tabular}{|c|c|c|}
\hline Organ & Manifestation & $\%$ \\
\hline \multirow[t]{7}{*}{ Skin } & Lentigines & $70-80$ \\
\hline & Blue nevus & 40 \\
\hline & Epitheliod blue nevus & \\
\hline & Cutaneous myxomas & $30-50$ \\
\hline & Café-au-lait spots & Rare \\
\hline & Depigmented lesions & Rare \\
\hline & Spitz nevus & Rare \\
\hline \multirow[t]{4}{*}{ Pituitary } & Somatomammotroph hyperplasia & 67 \\
\hline & $\begin{array}{l}\text { Asymptomatic elevation of GH, IGF1 or } \\
\text { prolactin }\end{array}$ & Up to 75 \\
\hline & GH-producing adenoma with acromegaly & $10-12$ \\
\hline & Prolactinomas & Rare \\
\hline \multirow[t]{5}{*}{ Eye } & Facial and palpebral lentigines & 70 \\
\hline & $\begin{array}{l}\text { Pigmented lesions of the caruncle or } \\
\text { conjuntival }\end{array}$ & 27 \\
\hline & semilunar fold & 16 \\
\hline & Eyelid myxomas & Rare \\
\hline & Pigmented schwannomas of the uvea & \\
\hline \multirow[t]{3}{*}{ Thyroid } & Cystic or Nodular disease & Up to 75 \\
\hline & Benign thyroid adenomas & Up to 25 \\
\hline & Thyroid cancer (papillary or follicular typ & Up to 10 \\
\hline Heart & Cardiac myxomas & $20-40$ \\
\hline \multirow[t]{3}{*}{ Pancreas } & Acinar cell carcinoma & \\
\hline & Adenocarcinoma & 2.5 \\
\hline & $\begin{array}{l}\text { Intraductal pancreatic mucinous } \\
\text { neoplasia (IPMN) }\end{array}$ & \\
\hline Liver & Hepatocellular adenoma & Rare \\
\hline \multirow[t]{2}{*}{ Adrenals } & PPNAD & $25-60$ \\
\hline & Adrenocortical cancer & Rare \\
\hline \multirow[t]{3}{*}{ Testes } & LCCSCT & 41 \\
\hline & Leydig-cell tumors & Rare \\
\hline & Adrenocortical rest tumors & Rare \\
\hline \multirow[t]{3}{*}{ Ovaries } & Ovarian cyst & \\
\hline & Seruscysadenomas & 14 \\
\hline & Cystic teratomas & \\
\hline \multirow[t]{3}{*}{ Breast } & Breast and nipple myxomas & \\
\hline & Ductal adenomas & 20 \\
\hline & Myxoid fibroadenomas & \\
\hline Uterus & Uterine myxoid tumors & Rare \\
\hline Bone & Osteochondromyxoma & Rare \\
\hline Nerve sheath & PMS & Up to 10 \\
\hline \multirow[t]{4}{*}{ Other organs } & Paratiroid mixed tumor & \\
\hline & Bronchogenic cyst & Rare \\
\hline & Colonic and gastric carcinoma & \\
\hline & Peritoneal fibrous histiocytomas & \\
\hline
\end{tabular}

layer, and usually they are symptomless and $<1 \mathrm{~cm}$ in diameter $(24,25)$. Rarely, a sharply circumscribed angiomyxoid nodule may be found (26).

\section{Ophthalmologic manifestations}

The most common ophthalmologic manifestations are facial and palpebral lentigines, pigmented lesions of the caruncle or conjuntival semilunar fold and eyelid myxomas $(27,28)$. There are some reports of pigmented 

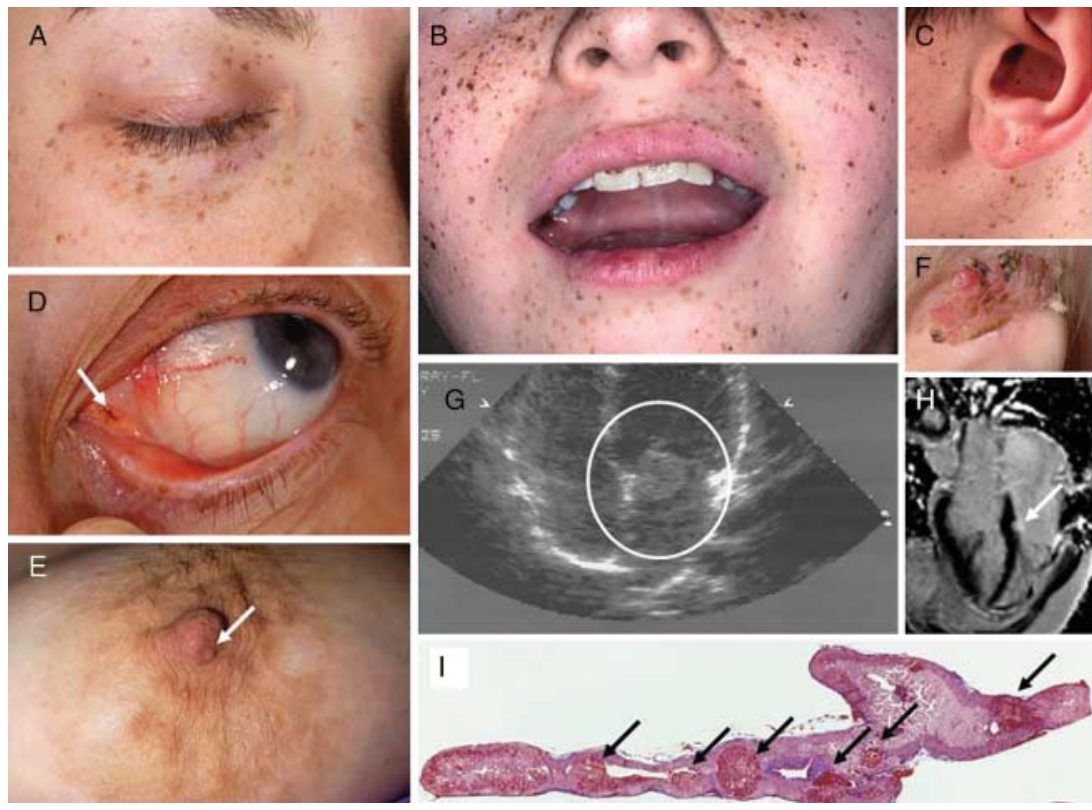

\section{Figure 1}

(A, B, and C) Manifestation of Carney complex. Characteristic distribution of the lentigines on the eyelids $(A)$, the vermillion border of the lips and the cheeks (B) and the ears, including the ear canal (C), in patients with CNC; such typical pigmentation on the face is only present in less than one-third of the patients, but it is rather diagnostic when present. (D) A pigmented macule (arrow) on the outer canthus of a patient with CNC who had minimal other pigmentation; inner or outer canthal pigmentation such as the one shown here is only seen in CNC and Peutz-Jeghers syndrome, making it diagnostic for these two conditions. (E) Nipple myxoma in a female patient with CNC. (F) Ear myxoma complicated by chronic infection and tissue overgrowth in a toddler with CNC. (G and H) Large myxoma (circled) between the left atrium and ventricle detected by echocardiography in an adolescent with CNC (G) who had surgery immediately thereafter, and a much smaller myxoma (arrow) of the left ventricle originating from the cardiac diaphragm detected by cardiac MRI in an older patient with CNC $(\mathrm{H})$; this myxoma was followed by serial echocardiogram and has yet to be operated, as it is not growing and poses no immediate risks. (I) $5 \times$ magnification hematoxylin and eosin staining of the adrenal gland of a patient with CNC: the characteristic nodules of PPNAD are shown by the arrows; the overall size of the gland is normal and the nodules may not be visible by imaging studies.

should be contrasted with that of sporadic cardiac myxomas that develop almost exclusively in the left atrium and are far more frequent in older female patients. Cardiac myxomas present with symptoms related to intracardiac obstruction of blood flow or embolic phenomenona (into the systemic circulation) like strokes and/or heart failure. They are responsible for more than $50 \%$ of the mortality of the disease $(1,2,12,13)$, myxomas can completely occlude a valvular orifice and may cause sudden death (14). This is why early detection and regular screening with echocardiography are essential $(1,32,33)$; cardiac CT or magnetic resonance imaging (MRI) may also be used for the detection of these tumors, especially in post-operative hearts with altered anatomy (34). males and females (Fig. $1 \mathrm{G}$ and $\mathrm{H}$ ). Their epidemiology 


\section{Pituitary tumors}

Up to $75 \%$ of CNC patients exhibit asymptomatic elevation of growth hormone $(\mathrm{GH})$, insulin-like growth factor1 (IGF1) or prolactin in the serum, abnormal response of GH to oral glucose tolerance test (OGTT) and 'paradoxical' response to thyrotropin (TSH)-releasing hormone without tumors detected on imaging studies $(31,35)$. The incidence of acromegaly due to pituitary tumors is around $10-12 \%$ in these patients $(11,12,13$, $36,37)$. The adenomas usually appear during or after the third decade of life. Histological investigation of these tumors revealed somatomammotrophic hyperplasia ( $\mathrm{SH}$ ). $\mathrm{SH}$ is a putative precursor of $\mathrm{GH}$-producing adenoma and may explain the protracted period of the onset of clinical acromegaly in individuals with CNC $(12,14)$. Patients can be followed by measuring GH and IGF1 levels and/or performing OGTT (11).

Rare prolactinomas have been also described (11). The tumors in operated CNC patients with acromegaly, frequently immunostained for both prolactin and alpha subunit in addition to GH. Interestingly, TSH, luteinizing hormone and follicle-stimulating hormone staining have also been seen in the foci of normal pituitary cells entrapped within the tumor or hyperplasia (38).

\section{Adrenocortical tumors}

The most common endocrine tumor in CNC is primary pigmented nodular adrenocortical disease (PPNAD), a cause of (adrenocorticotropin)-independent overproduction of cortisol (14). It affects between 25 and $60 \%$ of the individuals with CNC (70-71\% female and 21\% males) $(12,17,31)$.

Few CNC patients present with PPNAD during the first 2-3 years of life (11); most present in the first 30 years of life (the observed 'peak' of diagnosis is during the second and third decades of life) $(2,14)$. Histologic evidence of PPNAD has been found in almost every individual with CNC who underwent autopsy, showing that a number of patients have asymptomatic PPNAD.

In PPNAD (Fig. 1J), the adrenal cortex is peppered with small pigmented nodules $(<1 \mathrm{~cm})$ surrounded by usually atrophic cortex $(4,39)$. Cortisol production can be variable, often cyclical or periodic, is characterized by a paradoxical rise in response to dexamethasone administration $(2,17,40)$.

PPNAD continues to be a diagnostic challenge to the radiologist due to the small overall size of the adrenals and the small size of the pigmented nodules. To observe numerous pigmented nodules, CT slice thickness has to be $3 \mathrm{~mm}$ or less; if the slice thickness is $5 \mathrm{~mm}$ or more, the radiological report will be normal adrenals. The pigmented nodules are small, round, well delineated and hypodense compared to the rest of the adrenal parenchyma $(4,31)$.

Symptomatic individuals with PPNAD develop Cushing's syndrome. The hypercortisolism of PPNAD is usually insidious at onset (14). Cyclical and other forms of atypical Cushing's syndrome are also common among CNC patients (41).

Adrenocortical cancer has also been recently described in CNC patients. In those cases, co-secretion of androgen and cortisol and rapid occurrence of metastasis were observed (42).

\section{Thyroid neoplasms}

CNC patients may have thyroid nodules (up to $60 \%$ of all patients and two-thirds among children and adolescents) $(12,31,43)$; their histology varies from benign thyroid adenomas (mostly follicular) in $25 \%$ of the cases $(1,12)$ to otherwise nonspecific cystic disease in $75 \%$ of the cases (14), to the rare thyroid cancer (papillary or follicular type) in up to $10 \%$ of the cases $(2,44)$. Thyroid nodules often appear during the first 10 years of life in CNC patients (17). Despite thyroid nodularity, CNC patients are clinically and biochemically euthyroid $(43,45)$.

\section{Psammomatous melanotic schwannomas}

Psammomatous melanotic schwannomas (PMS) is a rare tumor of the nerve sheath that has been reported in patients with CNC (up to 10\%) $(12,14)$. PMS has frequent calcification and multi-centricity with heavy pigmentation and may be located anywhere in the central or peripheral nervous system $(46,47)$. The most frequent sites are in the gastrointestinal tract (esophagus, stomach, liver and rectum) and in the paraspinal sympathetic chain $(28 \%)(11,48)$. The chest wall, with involvement of adjacent ribs, is the third most common site (31). The spinal tumors present as pain and radiculopathy in adults (at a mean age of 32 years). Malignant degeneration occurs in $\sim 10 \%$ of PMS associated with CNC $(49,50)$.

\section{Testicular tumors}

More than three-quarters of males with $\mathrm{CNC}$ may have large cell-calcifying Sertoli cell tumors (LCCSCT). Lesions may be bilateral, palpable and multifocal, with some risk 
of malignancy and are associated with reduced fertility $(22,24,51)$. LCCSCT are detected by ultrasonography as multiple and bilateral testicular microcalcifications that distinguish them from germ cell and other testicular tumors $(2,26)$. Leydig-cell tumors or hyperplasia and adrenocortical rest tumors (affected by PPNAD) have also been reported in $\mathrm{CNC}$ patients and should be considered especially in male patients with CNC and sexual precocity (24).

\section{Breast tumors}

Breast myxomas, often bilateral, occur in females with CNC after puberty. Both males and females may develop nipple myxomas at any age (11). In addition, ductal adenomas and myxoid fibroadenomas have been reported $(12,52,53)$.

\section{Ovarian lesions}

Ovarian cysts and tumors of the ovarian surface epithelium, including serous cystadenomas and cystic teratomas have been reported in females with CNC. These are typically hypoechoic lesions by sonographic examination. They can grow or progress (rarely) to ovarian carcinoma $(11,12,54)$.

\section{Bone lesions}

Osteochondromyxoma is a rare component of $\mathrm{CNC}$ characterized by a myxomatous tumor of the bone that may affects any bone but has been seen most frequently in the nasal sinuses and the long bones of the upper and lower extremities (14). They usually appear early in life (before the age of 2) (2). These bone lesions are benign, but both local invasiveness and recurrence have been reported (11).

\section{Other lesions}

Hepatocellular adenoma was first reported in a 19-year-old female patient (55). Uterine myxoid tumors were also reported in a single patient (56). Pancreatic neoplasms including acinar cell carcinoma, adenocarcinoma and intraductal pancreatic mucinous neoplasia, were seen in as many as $2.5 \%$ of CNC patients $(12,57)$. Other tumors like parathyroid mixed tumor, bronchogenic cysts, colonic, gastric carcinoma and peritoneal fibrous histiocytomas have also been described in rare cases $(2,11)$.

\section{Diagnosis}

CNC should be suspected in patients with a suggestive phenotype (31). Table 2 lists the criteria for the diagnosis of $\mathrm{CNC}(1,2,5,11,15,17)$. A number of clinical and biochemical manifestations may also suggestive but they are not clearly diagnostic of CNC (sometimes these are mentioned as minor criteria) (Table 2) (58). The median age of diagnosis is 20 years (13). Depending on the affected organ and the type of lesion, there are other syndromes/ disorders that will have a similar presentation (Table 3 ) $(8,14,59,60,61,62,63,64,65,66)$.

\section{Treatment}

In CNC, each specific complication/tumor should be addressed separately. Cardiac myxomas should be removed surgically; most patients, however, have two or more open-heart surgeries for recurrent tumors $(11,31$, $67,68)$. SH and/or GH-producing pituitary adenomas may be treated medically with somastotatin analogues or removed surgically (49). Similarly, for PPNAD, the best treatment is surgical, by bilateral adrenalectomy; however, medical adrenalectomy with inhibitors of steroidogenesis such as ketoconazole or mitotane may also be considered in selected cases $(8,17,59,69)$. Surgical excision of cutaneous and mammary myxomas may be needed, but it is not always necessary as these tumors are completely benign. Fine-needle aspiration for thyroid nodules is recommended in suspicious cases $(2,11)$ and thyroid cancer may be treated as it is appropriate for the histologic subtype. Boys with LCCSCT may develop gynecomastia, premature epiphyseal fusion and induction of central precocious puberty, and for them surgery and/or treatment with aromatase inhibitors may be needed $(14,19,70)$. PMS is more difficult to treat because many of these tumors are located around nerve roots, a location that typically renders them inoperable (49). There is no effective treatment for metastatic PMS; CNC patients that develop metastatic PMS die of complications of the spread of the tumor usually in the lungs, liver or brain $(13,19)$.

\section{Surveillance and follow-up of patients with CNC}

Any patient with the diagnosis of $\mathrm{CNC}$ should be followed closely for clinical manifestations of the disease at least once a year. A study has shown that this type of follow-up improves prognosis $(13,58)$. 
Table 2 Diagnostic criteria for $\mathrm{CNC}^{\mathrm{a}}$.

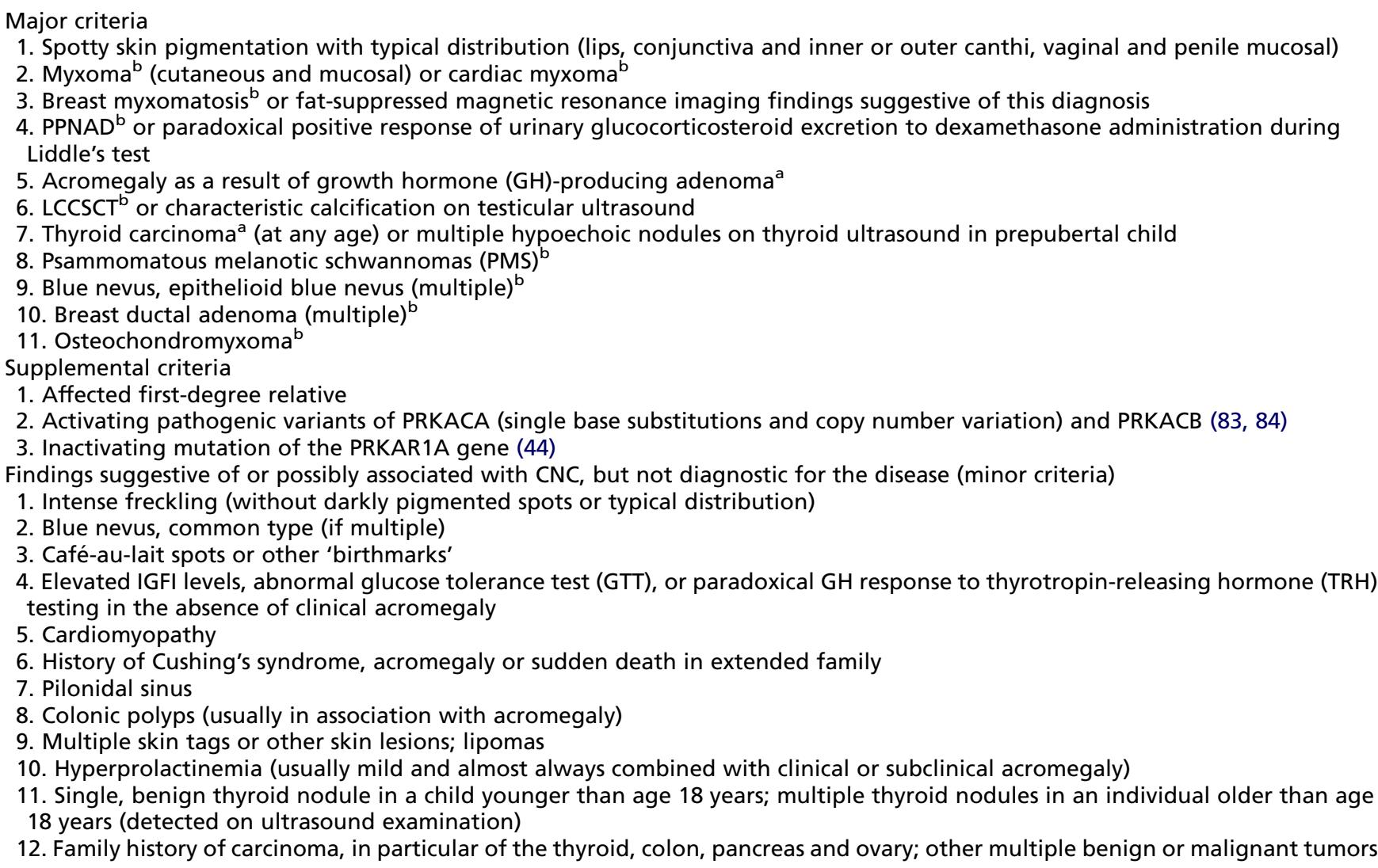

${ }^{a}$ To make the diagnosis of CNC, a patient must either (1) exhibit two of the major criteria confirmed by histology, imaging or biochemical testing or meet (2) one major criterion and one supplemental one.

${ }^{\mathrm{b}}$ With histologic confirmation.

The suggested studies $(71,72,73)$ include:

i) Annual echocardiogram, beginning in infancy; if a patient was diagnosed with a cardiac myxoma at least once, cardiac imaging may be done biannually.

ii) Regular skin evaluations.

iii) Blood tests to check serum levels of $\mathrm{GH}$, prolactin and IGF1 beginning in adolescence, as appropriate for the detection of GH and prolactin excess; urinary free cortisol and other testing for screening of Cushing's syndrome, as appropriate.

iv) Thyroid gland (neck) clinical examinations and with ultrasound, if needed.

v) Imaging may include adrenal computed tomography for the detection of PPNAD; pituitary MRI, and MRI of brain, spine, chest, abdomen, retroperitoneum and pelvis for the detection of PMS (14).

vi) In males, testicular examinations with ultrasound may be done annually for the detection and followup of LCCSCT. vii) In females, transabdominal ultrasound of the ovaries (baseline examination; it may be repeated, as needed) (10).

viii) In pre-pubertal children: close monitoring of linear growth rate and annual pubertal staging (14).

\section{Prognosis}

The historic adjusted average life span for patients with CNC is 50-55 years, but with careful surveillance, life expectancy may be normal. The most common causes of death are related to complications of heart myxomas, such as emboli (strokes), post-operative cardiomyopathy and cardiac arrhythmias, as well as metastatic PMS, pancreatic and other cancers $(14,62,74)$.

\section{Genetics}

CNC is caused by mutations in the PRKAR1A gene (OMIM 188830) coding for the regulatory subunit type I alpha of 
Table 3 Conditions to be considered in the differential diagnosis of CNC per tissue manifestation.

Organ

Skin (lentigines)

Skin (café-au-lait spots)

Skin (blue nevi) Thyroid (tumors)

Testes (large-cell calcifying Sertoli cell tumor (LCCSCT)) Ovarian (tumors)

Adrenals

Adrenocortical tumors

Pituitary (GH-secreting adenoma)

Schwannomas

\begin{tabular}{l} 
Related disorders \\
\hline Sporadic myxomas \\
Adults: most common type of \\
cardiac tumor \\
Children: 30\% of cardiac \\
tumor \\
Familial myxomas due to \\
mutation of a protein of the \\
myosin family \\
Familial lentiginosis, Peutz- \\
Jeghers syndrome, LEOPARD \\
syndrome, Noonan \\
syndrome with lentiginosis, \\
Bannayan-Riley-Ruvalcaba \\
syndrome \\
McCune-Albright syndrome, \\
neurofibromatosis type 1, \\
neurofibromatosis type 2, \\
Watson syndrome \\
Solitary lesions \\
Cowden syndrome, sporadic \\
thyroid tumors \\
Peutz-Jeghers syndrome \\
Peutz-Jeghers syndrome \\
Sporadic isolated primary \\
pigmented nodular adreno- \\
cortical disease (PPNAD) \\
Isolated micronodular \\
adrenocortical hyperplasia \\
Beckwith-Wiedemann \\
syndrome, Li-Fraumeni \\
syndrome, multiple \\
endocrine neoplasia type 1 \\
(MEN1), congenital adrenal \\
hyperplasia resulting from \\
21-hydroxylase deficiency, \\
McCune-Albright syndrome \\
MEN1, isolated familial \\
somatotropinomas (IFS), \\
sporadic somatotropinomas \\
Neurofibromatosis type 1, \\
neurofibromatosis type 2, \\
schwannomatosis
\end{tabular}

patients with adrenal hyperplasias but not in $\mathrm{CNC}$. PRKACB CNG has only been seen in one patient with CNC. For the majority of the PRKAR1A-negative CNC cases the genetic cause remains unknown.

To date, more than 125 PRKAR1A pathogenic mutations have been reported (http://prkar1a.nichd.nih. gov/hmdb/intro.html) in 401 unrelated families of diverse ethnic origin (Table 4) $(12,61,78,79)$. The PRKAR1A pathogenic mutations include single-base substitutions, small ( $\leq 15 \mathrm{bp}$ ) deletions/insertions, combined rearrangements that are spread along the whole open reading frame of the gene and large deletions that cover most of the exons and in some cases the whole gene locus $(70,78,80)$. Most of these mutations are unique (presented in a single kindred), and only three pathogenic variants (c.82C $>$ T, c.491_492delTG and c.709-2_709-7 delATTTTT) have been identified in more than three unrelated pedigrees $(10,12,81)$

A second genetic locus is associated with $\mathrm{CNC}$ and it is referred to as the 'CNC2' locus (CNC1 being the PRKAR1A gene $17 \mathrm{q}$ locus) (Table 4 ). CNC2 is a $10 \mathrm{Mb}$ region in the 2p16 locus that has been detected through linkage analysis in PRKAR1A-negative patients with CNC and further delineated by copy number changes in $\mathrm{CNC}$ tumors $(12,78,82)$. To date, the gene(s) residing in the 2 p16 region that may be responsible for a CNC phenotype or progression of its tumors remain(s) unknown.

Two recent studies associated elements of the CNC phenotype with PRKACA and PRKACB gene defects (Table 4). Comparative genomic hybridization (CGH) in 35 patients with cortisol-producing bilateral adrenal hyperplasia and overt Cushing's syndrome identified five patients with CNGs of the genomic region that included the PRKACA gene on chromosome 19 (83). In a single individual with $\mathrm{CNC}$, developmental delay and skeletal defects were identified; in her, the disease was caused by somatic PRKACB gene locus CNGs on chromosome 1 (84). The precise roles of PRKACA and PRKACB in the CNC phenotype remain to be elucidated.

\section{Molecular pathogenesis of CNC: PKA and its subunits}

PRKAR1A gene encodes for the most widely expressed regulatory subunit of the PKA enzyme. The PKA heterotetramer consists of two regulatory (R) and two catalytic (C) subunits. Stimulation of adenyl cyclases through $\mathrm{G}$ protein subunit (Gs) activation leads to cAMP synthesis (Fig. 2). cAMP, binds to the regulatory subunits and leads to their dissociation from the catalytic subunits. 
Table 4 Genomic locus and genes/mutations associated with CNC.

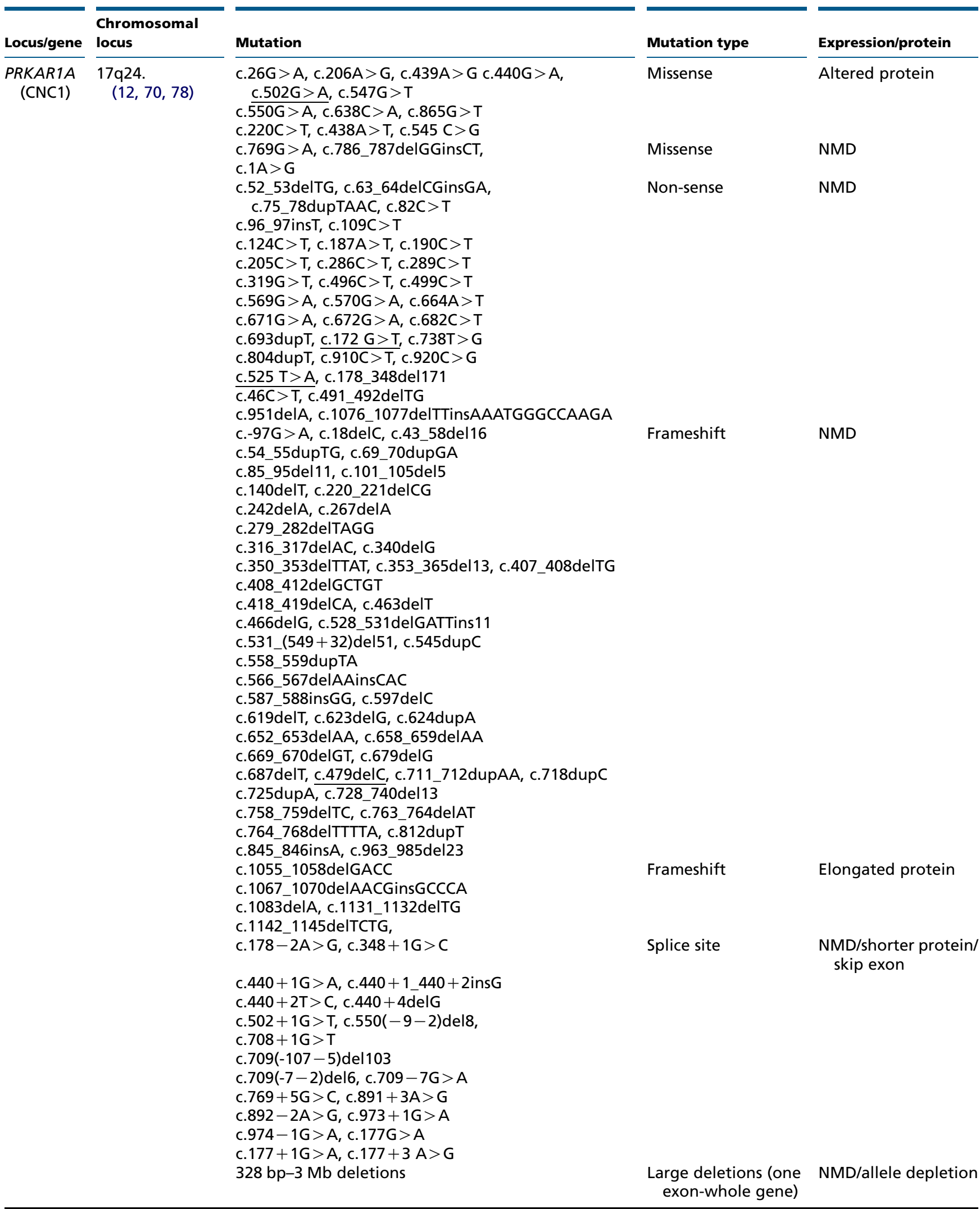


Table 4 Continued

\begin{tabular}{|c|c|c|c|c|}
\hline Locus/gene & $\begin{array}{l}\text { Chromosomal } \\
\text { locus }\end{array}$ & Mutation & Mutation type & Expression/protein \\
\hline CNC2 & 2p16 (82) & NA & NA & NA \\
\hline PRKACA & $19 p 13.1(83)$ & $294 \mathrm{~Kb}-2.7 \mathrm{Mb}$ & $\begin{array}{l}\text { Large gene } \\
\text { amplification }\end{array}$ & Overexpression \\
\hline$P R K A C B$ & $1 \mathrm{p} 31.1$ (84) & $1.6 \mathrm{Mb}$ & $\begin{array}{l}\text { Large gene } \\
\text { amplification }\end{array}$ & Overexpression \\
\hline
\end{tabular}

NMD, nonsense-mediated mRNA decay (NMD) mechanism (http://prkar1a.nichd.nih.gov/hmdb/intro.html). When a mutation is underlined, pathogenesis analyzed with in silico analysis; when the mutation is not underlined, its pathogenesis was confirmed in vitro.

The catalytic subunits after their dissociation from the PKA complex phosphorylate many downstream factors such as the CREB (Fig. 2). PRKAR1A defects associated with CNC lead to PRKAR1A haploinsufficiency and, thus, to the loss of this regulatory subunit's function: 'unrestrained' catalytic subunit activity leads to increased cell proliferation in cAMP-responsive tissues and tumor formation in tissues affected by CNC $(10,85)$.

Almost all PRKAR1A nonsense substitutions, small insertions/deletions, variations of splicing sites lead to frame shifts and/or premature stop codons that result in shorter or otherwise defective mRNAs, which are not encoded to protein because they are degraded by the nonsense-mediated mRNA decay (NMD) surveillance mechanism $(10,79,86)$. Large deletions that include the whole gene also lead to PRKAR1A haploinsufficiency and almost half the protein levels compared to normal cells $(70,80)$.

Rarely, missense mutations of the PRKAR1A gene, short in-frame insertions/deletions and splice variants that are expressed at the protein level (because NMD is not activated) lead to the disease, not due to haploinsufficiency but to a defective protein that fails to respond appropriately to cAMP or does not bind effectively to the PKA catalytic subunits $(87,88)$. Mutations that give rise to alternate splice sites may also be pathogenic by either leading to mRNA that is subject to NMD or a protein that does not bind appropriately to cAMP or the catalytic subunits (81). Some PRKAR1A mutations lead to a longer protein due to the loss of the stop codon normally situated in the last coding exon that is not subject to NMD. These longer PRKAR1A proteins undergo proteosomal degradation resulting again in PRKAR1A haploinsufficiency (89).

There are groups of $\mathrm{CNC}$ patients who show specific genotype-phenotype correlation, and this also explains the CNC heterogeneity $(12,79)$. For example, mutation c.709-7del6 is present in most patients with isolated PPNAD (81), and most of the remaining were c. $1 \mathrm{~A}>\mathrm{G}$ carriers (79). It is difficult to conceive what molecular mechanisms underlie these phenotypic differences, since all these mutations lead to NMD. One suggestion is that small amounts of mutant RI $\alpha$ protein are in fact

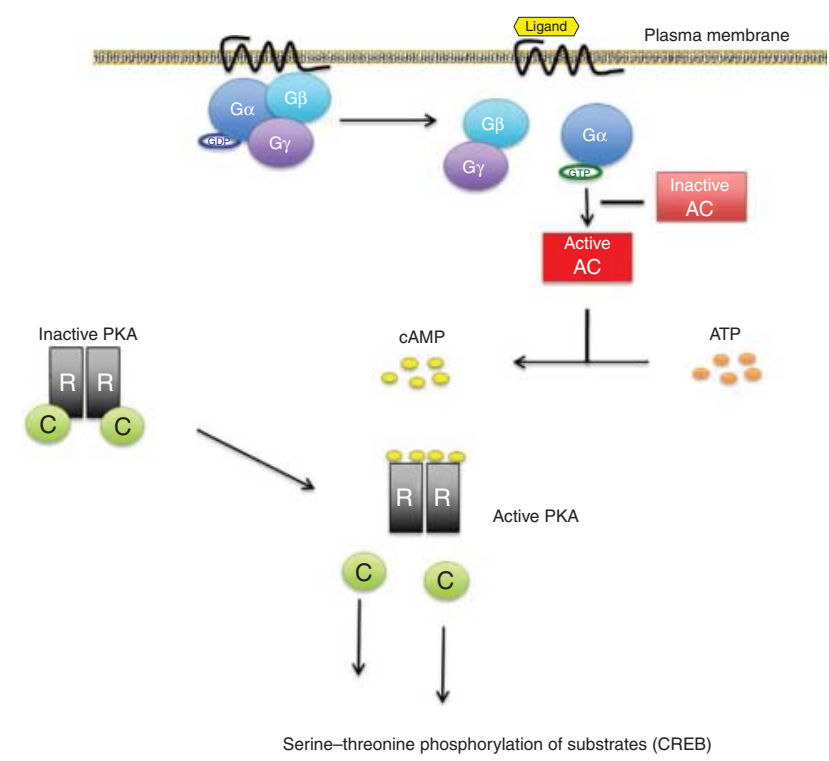

Figure 2

cAMP pathway activation. Receptor activation (ligand binding) makes Ga to exchange GDP to GTP, Ga is then freed from the $\mathrm{G} \beta-\mathrm{G} \gamma$ dimer and activates adenyl cyclase (AC). Activated AC produces CAMP from ATP, CAMP causes dissociation of the inactive protein kinase $A$ (PKA) tetramer and then the catalytic subunits are freed to mediate serine-threonine phosphorylation of target molecules, including CREB. PRKAR1A inactivating mutations in Carney complex patients will result in less binding of the catalytic to the regulatory subunits and excessive CAMP signaling. 
produced at least in certain tissues. These phenotypegenotype correlations can be due to their high frequency, and that additional phenotypic differences between the various PRKAR1A mutations leading to NMD will emerge as the number of observations increases. On the other hand, mutations that lead to an alternate PRKAR1A protein and not NMD (see Table 1) are associated with an overall higher total number of CNC manifestations and this could be due to a dominant-negative effect of the expressed mutant protein $(5,12,78)$.

Mouse models have been created in order to study the role of PRKAR1A in CNC and the ability to cause CNC phenotypes. Prkar1a+/ - mice developed non-pigmented schwannomas and fibro-osseous bone lesions beginning around 6 months of age. Later in life, $10 \%$ of the mice also developed thyroid tumors (90). Another mouse model that had significantly higher Prkar1a down-regulation and significantly higher cAMP signaling produced a more severe CNC phenotype (91).

In the cases where PRKACA and PRKACB amplification was found, the mechanism of disease is presumed to be increased free PKA catalytic subunit activity (83). Although the molecular stoichiometry of how this occurs remains to be studied in vitro and in animal studies, tissues from patients with PRKACA and PRKACB CNG both had increased PKA activity (83). This is less clearly understood in the single patient with $P R K A C B$ gene amplification, since based on what is known about PKA, two additional copies of the gene (and modestly higher $C \beta$ protein levels) should have had minimal effects on total PKA activity; nevertheless, the defect led to an unquestionable phenotype of CNC with pigmented spots, myxomas and a growth-hormone (GH)-producing pituitary tumor (84).

\section{Genetic counseling}

The identification of a pathogenic variant in the PRKAR1A gene can be used for diagnosing CNC. Molecular testing may be suggested then for relatives, or for new patients with two or more diagnostic criteria. If sequencing of the PRKAR1A gene does not show a defect, copy number variant analysis by CGH and/or deletion PRKAR1A gene deletion testing may be needed to rule out a PRKAR1A defect. If all testing is negative for PRKAR1A defects, other candidate genes or loci may be screened including the PRKACA, PRKACB and the phosphodiesterase genes. However, the latter are mostly limited to research at this point.
Declaration of interest

The authors declare that there is no conflict of interest that could be perceived as prejudicing the impartiality of the review.

\section{Funding}

This study was supported by the intramural research program of NICHD, $\mathrm{NIH}$.

\section{Acknowledgements}

We thank Diane Cooper, NIH Library, for providing assistance in writing this manuscript.

\section{References}

1 Sandrini F \& Stratakis C. Clinical and molecular genetics of Carney complex. Molecular Genetics and Metabolism 200378 83-92. (doi:10.1016/S1096-7192(03)00006-4)

2 Stratakis CA, Kirschner LS \& Carney JA. Clinical and molecular features of the Carney complex: diagnostic criteria and recommendations for patient evaluation. Journal of Clinical Endocrinology and Metabolism 2001 86 4041-4046. (doi:10.1210/jcem.86.9.7903)

3 Atherton DJ, Pitcher DW, Wells RS \& MacDonald DM. A syndrome of various cutaneous pigmented lesions, myxoid neurofibromata and atrial myxoma: the NAME syndrome. British Journal of Dermatology 1980 103 421-429. (doi:10.1111/j.1365-2133.1980.tb07266.x)

4 Carney JA, Gordon H, Carpenter PC, Shenoy BV \& Go VL. The complex of myxomas, spotty pigmentation, and endocrine overactivity. Medicine 198564 270-283. (doi:10.1097/00005792-198507000-00007)

5 Bain J. Carney's complex. Mayo Clinic Proceedings 198661508. (doi:10.1016/S0025-6196(12)61989-2)

6 Boikos SA \& Stratakis CA. Carney complex: pathology and molecular genetics. Neuroendocrinology 200683 189-199. (doi:10.1159/ 000095527)

7 Akbas H, Kirali K, Daglar B, Kutay V, Isik O \& Yakut C. Surgical treatment of left-atrial myxoma in Carney's complex. Thoracic and Cardiovascular Surgeon 199745 148-150. (doi:10.1055/s-2007-1013711)

8 Stratakis CA. Genetics of Carney complex and related familial lentiginoses, and other multiple tumor syndromes. Frontiers in Bioscience 20005 D353-D366. (doi:10.2741/Stratakis)

9 Rhodes AR, Silverman RA, Harrist TJ \& Perez-Atayde AR. Mucocutaneous lentigines, cardiomucocutaneous myxomas, and multiple blue nevi: the "LAMB" syndrome. Journal of the American Academy of Dermatology 198410 72-82. (doi:10.1016/S0190-9622(84)80047-X)

10 Kirschner LS, Carney JA, Pack SD, Taymans SE, Giatzakis C, Cho YS Cho-Chung YS \& Stratakis CA. Mutations of the gene encoding the protein kinase A type I- $\alpha$ regulatory subunit in patients with the Carney complex. Nature Genetics 200026 89-92. (doi:10.1038/79238)

11 Espiard S \& Bertherat J. Carney complex. Frontiers of Hormone Research 201341 50-62. (doi:10.1159/000345669)

12 Bertherat J, Horvath A, Groussin L, Grabar S, Boikos S, Cazabat L, Libe R, Rene-Corail F, Stergiopoulos S, Bourdeau I et al. Mutations in regulatory subunit type $1 \mathrm{~A}$ of cyclic adenosine $5^{\prime}$-monophosphate-dependent protein kinase (PRKAR1A): phenotype analysis in 353 patients and 80 different genotypes. Journal of Clinical Endocrinology and Metabolism 200994 2085-2091. (doi:10.1210/jc.2008-2333)

13 Boikos SA \& Stratakis CA. Carney complex: the first 20 years. Current Opinion in Oncology 200719 24-29. (doi:10.1097/CCO.0b013e $32801195 \mathrm{eb})$ 
14 Stratakis CA, Salpea P \& Raygada M. Carney complex. In GeneReviews(R). Eds RA Pagon, MP Adam, HH Ardinger, SE Wallace, A Amemiya, LJH Bean, TD Bird, CR Dolan, CT Fong, RJH Smith \& K Stephens. SourceGeneReviews ${ }^{\circledR}$. Seattle (WA): University of Washington, Seattle; 1993-2015. 2003 Feb 5 [updated 2015 Jan 29] (accessed on Feb 26, 2015).

15 Mateus C, Palangie A, Franck N, Groussin L, Bertagna X, Avril MF, Bertherat J \& Dupin N. Heterogeneity of skin manifestations in patients with Carney complex. Journal of the American Academy of Dermatology 200859 801-810. (doi:10.1016/j.jaad.2008.07.032)

16 Horvath A \& Stratakis CA. Carney complex and lentiginosis. Pigment Cell \& Melanoma Research 200922 580-587. (doi:10.1111/j.1755-148X. 2009.00613.x)

17 Rothenbuhler A \& Stratakis CA. Clinical and molecular genetics of Carney complex. Best Practice \& Research. Clinical Endocrinology \& Metabolism 201024 389-399. (doi:10.1016/j.beem.2010.03.003)

18 Carney JA \& Stratakis CA. Epithelioid blue nevus and psammomatous melanotic schwannoma: the unusual pigmented skin tumors of the Carney complex. Seminars in Diagnostic Pathology 199815 216-224.

19 Stratakis CA, Kirschner LS \& Carney JA. Carney complex: diagnosis and management of the complex of spotty skin pigmentation, myxomas, endocrine overactivity, and schwannomas. American Journal of Medical Genetics 199880 183-185. (doi:10.1002/(SICI)1096-8628(19981102) 80:2<183::AID-AJMG19>3.0.CO;2-I)

20 Stratakis CA \& Kirschner LS. Isolated familial somatotropinomas: does the disease map to 11q13 or to 2p16? Journal of Clinical Endocrinology and Metabolism 200085 4920-4921. (doi:10.1210/jcem.85.12.7076-1)

21 Stratakis CA. Genetics of Peutz-Jeghers syndrome, Carney complex and other familial lentiginoses. Hormone Research 200054 334-343. (doi:10.1159/000053283)

22 Vandersteen A, Turnbull J, Jan W, Simpson J, Lucas S, Anderson D, Lin JP, Stratakis C, Pichert G \& Lim M. Cutaneous signs are important in the diagnosis of the rare neoplasia syndrome Carney complex. European Journal of Pediatrics 2009168 1401-1404. (doi:10.1007/ s00431-009-0935-y)

23 Carney JA \& Ferreiro JA. The epithelioid blue nevus. A multicentric familial tumor with important associations, including cardiac myxoma and psammomatous melanotic schwannoma. American Journal of Pathology 199620 259-272. (doi:10.1097/00000478-199603000-00001)

24 Wilkes D, McDermott DA \& Basson CT. Clinical phenotypes and molecular genetic mechanisms of Carney complex. Lancet. Oncology 20056 501-508. (doi:10.1016/S1470-2045(05)70244-8)

25 Carney JA, Headington JT \& Su WP. Cutaneous myxomas. A major component of the complex of myxomas, spotty pigmentation, and endocrine overactivity. Archives of Dermatology 1986122 790-798. (doi:10.1001/archderm.1986.01660190068018)

26 Hachisuka J, Ichikawa M, Moroi Y, Urabe K \& Furue M. A case of Carney complex. International Journal of Dermatology 200645 1406-1407. (doi:10.1111/j.1365-4632.2006.02889.x)

27 Kennedy RH, Waller RR \& Carney JA. Ocular pigmented spots and eyelid myxomas. American Journal of Ophthalmology 1987104 533-538. (doi:10.1016/S0002-9394(14)74112-1)

28 Chinchurreta-Capote A, Trueba A, Hernandez FJ, Pinas P, Lopez S, Tena ME, Aznarez N, Portillo E \& Castillon L. Ocular findings in Carney complex. Archivos de la Sociedad Española de Oftalmología $2006 \mathbf{8 1}$ 709-711.

29 Saavedra E, Singh AD, Sears JE \& Ratliff NB. Plexiform pigmented schwannoma of the uvea. Survey of Ophthalmology 200651 162-168. (doi:10.1016/j.survophthal.2005.12.004)

30 Tsilou ET, Chan CC, Sandrini F, Rubin BI, Shen DF, Carney JA, KaiserKupfer M \& Stratakis CA. Eyelid myxoma in Carney complex without PRKAR1A allelic loss. American Journal of Medical Genetics. Part A 2004 130A 395-397. (doi:10.1002/ajmg.a.30279)

31 Courcoutsakis NA, Tatsi C, Patronas NJ, Lee CC, Prassopoulos PK \& Stratakis CA. The complex of myxomas, spotty skin pigmentation and endocrine overactivity (Carney complex): imaging findings with clinical and pathological correlation. Insights into Imaging 20134 119-133. (doi:10.1007/s13244-012-0208-6)

32 Mabuchi T, Shimizu M, Ino H, Yamguchi M, Terai H, Fujino N, Nagata M, Sakata K, Inoue M, Yoneda T et al. PRKAR1A gene mutation in patients with cardiac myxoma. International Journal of Cardiology 2005102 273-277. (doi:10.1016/j.ijcard.2004.05.053)

33 Lee B, Sir JJ, Park SW, Kim SB, Nah JC, Kang YK, Lee HK, Kim YI, Cho WH \& Choi SK. Right-sided myxomas with extramedullary hematopoiesis and ossification in Carney complex. International Journal of Cardiology 2008130 e63-e65. (doi:10.1016/j.ijcard. 2007.11.061)

34 Bireta C, Popov AF, Schotola H, Trethowan B, Friedrich M, El-Mehsen M, Schoendube FA \& Tirilomis T. Carney-complex: multiple resections of recurrent cardiac myxoma. Journal of Cardiothoracic Surgery 20116 12. (doi:10.1186/1749-8090-6-12)

35 Boikos SA \& Stratakis CA. Pituitary pathology in patients with Carney complex: growth-hormone producing hyperplasia or tumors and their association with other abnormalities. Pituitary 20069 203-209. (doi:10.1007/s11102-006-0265-2)

36 Pack SD, Kirschner LS, Pak E, Zhuang Z, Carney JA \& Stratakis CA. Genetic and histologic studies of somatomammotropic pituitary tumors in patients with the "complex of spotty skin pigmentation, myxomas, endocrine overactivity and schwannomas" (Carney complex). Journal of Clinical Endocrinology and Metabolism 200085 3860-3865. (doi:10.1210/jcem.85.10.6875)

37 Iwata T, Tamanaha T, Koezuka R, Tochiya M, Makino H, Kishimoto I, Mizusawa N, Ono S, Inoshita N, Yamada S et al. Germline deletion and a somatic mutation of the PRKAR1A gene in a Carney complex-related pituitary adenoma. European Journal of Endocrinology 2015172 K5-10. (doi:10.1530/EJE-14-0685)

38 Jones GN, Manchanda PK, Pringle DR, Zhang M \& Kirschner LS. Mouse models of endocrine tumours. Best Practice \& Research. Clinical Endocrinology \& Metabolism 201024 451-460. (doi:10.1016/j.beem. 2010.01.004)

39 Shenoy BV, Carpenter PC \& Carney JA. Bilateral primary pigmented nodular adrenocortical disease. Rare cause of the Cushing syndrome. American Journal of Pathology 19848 335-344. (doi:10.1097/00000478198405000-00002)

40 Louiset E, Stratakis CA, Perraudin V, Griffin KJ, Libe R, Cabrol S, Feve B, Young J, Groussin L, Bertherat J et al. The paradoxical increase in cortisol secretion induced by dexamethasone in primary pigmented nodular adrenocortical disease involves a glucocorticoid receptormediated effect of dexamethasone on protein kinase A catalytic subunits. Journal of Clinical Endocrinology and Metabolism 200994 2406-2413. (doi:10.1210/jc.2009-0031)

41 Stratakis CA \& Kirschner LS. Clinical and genetic analysis of primary bilateral adrenal diseases (micro- and macronodular disease) leading to Cushing syndrome. Hormone and Metabolic Research 199830 456-463. (doi:10.1055/s-2007-978914)

42 Bertherat J. Adrenocortical cancer in Carney complex: a paradigm of endocrine tumor progression or an association of genetic predisposing factors? Journal of Clinical Endocrinology and Metabolism 201297 387-390. (doi:10.1210/jc.2011-3327)

43 Stratakis CA, Courcoutsakis NA, Abati A, Filie A, Doppman JL, Carney JA \& Shawker T. Thyroid gland abnormalities in patients with the syndrome of spotty skin pigmentation, myxomas, endocrine overactivity, and schwannomas (Carney complex). Journal of Clinical Endocrinology and Metabolism 199782 2037-2043. (doi:10.1210/jcem. 82.7.4079)

44 Bossis I, Voutetakis A, Bei T, Sandrini F, Griffin KJ \& Stratakis CA. Protein kinase A and its role in human neoplasia: the Carney complex paradigm. Endocrine-Related Cancer 200411 265-280. (doi:10.1677/erc. $0.0110265)$

45 Pringle DR, Yin Z, Lee AA, Manchanda PK, Yu L, Parlow AF, Jarjoura D, La Perle KM \& Kirschner LS. Thyroid-specific ablation of the Carney complex gene, PRKAR1A, results in hyperthyroidism and follicular 
thyroid cancer. Endocrine-Related Cancer 201219 435-446. (doi:10.1530/ERC-11-0306)

46 Carney JA. Psammomatous melanotic schwannoma. A distinctive, heritable tumor with special associations, including cardiac myxoma and the Cushing syndrome. American Journal of Pathology 199014 206-222. (doi:10.1097/00000478-199003000-00002)

47 Rodriguez FJ, Stratakis CA \& Evans DG. Genetic predisposition to peripheral nerve neoplasia: diagnostic criteria and pathogenesis of neurofibromatoses, Carney complex, and related syndromes. Acta Neuropathologica 2012123 349-367. (doi:10.1007/s00401-011-0935-7)

48 Utiger CA \& Headington JT. Psammomatous melanotic schwannoma. A new cutaneous marker for Carney's complex. Archives of Dermatology 1993129 202-204. (doi:10.1001/archderm.1993.01680230086011)

49 Watson JC, Stratakis CA, Bryant-Greenwood PK, Koch CA, Kirschner LS, Nguyen T, Carney JA \& Oldfield EH. Neurosurgical implications of Carney complex. Journal of Neurosurgery 200092 413-418. (doi:10.3171/jns.2000.92.3.0413)

50 Shields LB, Glassman SD, Raque GH \& Shields CB. Malignant psammomatous melanotic schwannoma of the spine: a component of Carney complex. Surgical Neurology International 20112136. (doi:10.4103/2152-7806.85609)

51 Brown B, Ram A, Clayton P \& Humphrey G. Conservative management of bilateral Sertoli cell tumors of the testicle in association with the Carney complex: a case report. Journal of Pediatric Surgery $2007 \mathbf{4 2}$ E13-E15. (doi:10.1016/j.jpedsurg.2007.06.008)

52 Azzopardi JG \& Salm R. Ductal adenoma of the breast: a lesion which can mimic carcinoma. Journal of Pathology 1984144 15-23. (doi:10.1002/path.1711440103)

53 Carney JA \& Toorkey BC. Ductal adenoma of the breast with tubular features. A probable component of the complex of myxomas, spotty pigmentation, endocrine overactivity, and schwannomas. American Journal of Pathology 199115 722-731. (doi:10.1097/00000478199108000-00002)

54 Stratakis CA, Papageorgiou T, Premkumar A, Pack S, Kirschner LS, Taymans SE, Zhuang Z, Oelkers WH \& Carney JA. Ovarian lesions in Carney complex: clinical genetics and possible predisposition to malignancy. Journal of Clinical Endocrinology and Metabolism 200085 4359-4366. (doi:10.1210/jcem.85.11.6921)

55 Gennari M, Stratakis CA, Hovarth A, Pirazzoli P \& Cicognani A. A novel PRKAR1A mutation associated with hepatocellular carcinoma in a young patient and a variable Carney complex phenotype in affected subjects in older generations. Clinical Endocrinology 200869 751-755. (doi:10.1111/j.1365-2265.2008.03286.x)

56 Barlow JF, Abu-Gazeleh S, Tam GE, Wirtz PS, Ofstein LC, O'Brien CP, Woods GL \& Drymalski WG. Myxoid tumor of the uterus and right atrial myxomas. South Dakota Journal of Medicine 198336 9-13.

57 Gaujoux S, Tissier F, Ragazzon B, Rebours V, Saloustros E, Perlemoine K, Vincent-Dejean C, Meurette G, Cassagnau E, Dousset B et al. Pancreatic ductal and acinar cell neoplasms in Carney complex: a possible new association. Journal of Clinical Endocrinology and Metabolism 201196 E1888-E1895. (doi:10.1210/jc.2011-1433)

58 Stergiopoulos SG \& Stratakis CA. Human tumors associated with Carney complex and germline PRKAR1A mutations: a protein kinase A disease!. FEBS Letters 2003546 59-64. (doi:10.1016/S00145793(03)00452-6)

59 Horvath A, Boikos S, Giatzakis C, Robinson-White A, Groussin L, Griffin KJ, Stein E, Levine E, Delimpasi G, Hsiao HP et al. A genome-wide scan identifies mutations in the gene encoding phosphodiesterase 11A4 (PDE11A) in individuals with adrenocortical hyperplasia. Nature Genetics 200638 794-800. (doi:10.1038/ng1809)

60 Groussin L, Jullian E, Perlemoine K, Louvel A, Leheup B, Luton JP, Bertagna X \& Bertherat J. Mutations of the PRKAR1A gene in Cushing's syndrome due to sporadic primary pigmented nodular adrenocortical disease. Journal of Clinical Endocrinology and Metabolism 200287 4324-4329. (doi:10.1210/jc.2002-020592)
61 Veugelers M, Bressan M, McDermott DA, Weremowicz S, Morton CC, Mabry CC, Lefaivre JF, Zunamon A, Destree A, Chaudron JM et al. Mutation of perinatal myosin heavy chain associated with a Carney complex variant. New England Journal of Medicine 2004351 460-469. (doi:10.1056/NEJMoa040584)

62 Fogt F, Zimmerman RL, Hartmann CJ, Brown CA \& Narula N. Genetic alterations of Carney complex are not present in sporadic cardiac myxomas. International Journal of Molecular Medicine 20029 59-60. (doi:10.3892/ijmm.9.1.59)

63 Kjellman M, Larsson C \& Backdahl M. Genetic background of adrenocortical tumor development. World Journal of Surgery 200125 948-956. (doi:10.1007/s00268-001-0034-3)

64 Frohman LA. Isolated familial somatotropinomas: clinical and genetic considerations. Transactions of the American Clinical and Climatological Association 2003114 165-177.

65 Yamasaki H, Mizusawa N, Nagahiro S, Yamada S, Sano T, Itakura M \& Yoshimoto K. GH-secreting pituitary adenomas infrequently contain inactivating mutations of PRKAR1A and LOH of 17q23-24. Clinical Endocrinology 200358 464-470. (doi:10.1046/j.1365-2265. 2003.01740.x)

66 Sandrini F, Kirschner LS, Bei T, Farmakidis C, Yasufuku-Takano J, Takano K, Prezant TR, Marx SJ, Farrell WE, Clayton RN et al. PRKAR1A, one of the Carney complex genes, and its locus (17q22-24) are rarely altered in pituitary tumours outside the Carney complex. Journal of Medical Genetics 200239 e78. (doi:10.1136/jmg.39.12.e78)

67 McCarthy PM, Piehler JM, Schaff HV, Pluth JR, Orszulak TA, Vidaillet HJ Jr \& Carney JA. The significance of multiple, recurrent, and "complex" cardiac myxomas. Journal of Thoracic and Cardiovascular Surgery 198691 389-396.

68 Carney JA. Carney complex: the complex of myxomas, spotty pigmentation, endocrine overactivity, and schwannomas. Seminars in Dermatology 199514 90-98. (doi:10.1016/S1085-5629(05)80003-3)

69 Cignarelli M, Picca G, Campo M, Margaglione M, Marino A, Logoluso F $\&$ Giorgino F. A six month mitotane course induced sustained correction of hypercortisolism in a young woman with PPNAD and Carney complex. Journal of Endocrinological Investigation 200528 54-60. (doi:10.1007/BF03345530)

70 Salpea P, Horvath A, London E, Faucz FR, Vetro A, Levy I, Gourgari E, Dauber A, Holm IA, Morrison PJ et al. Deletions of the PRKAR1A locus at 17q24.2-q24.3 in Carney complex: genotype-phenotype correlations and implications for genetic testing. Journal of Clinical Endocrinology and Metabolism 201499 E183-E188. (doi:10.1210/jc.2013-3159)

71 Board CNE. Carney complex. In Cancer. Net. Ed ASoCOA- Cancer. Net., 2012. (http://www.cancer.net/cancer-types/carney-complex) (accessed on February 27, 2015)

72 Developement NIoCHaH. Recommended clinical surveillance of patients with CNC (PDF). 2014. (http://segen.nichd.nih.gov/ documents/Carney_Complex_Pt_Educ_Handout_FINAL.pdf) (accessed on March 1, 2015)

73 Robson ME, Storm CD, Weitzel J, Wollins DS, Offit K \& American Society of Clinical Oncology . American Society of Clinical Oncology policy statement update: genetic and genomic testing for cancer susceptibility. Journal of Clinical Oncology 201028 893-901. (doi:10.1200/JCO.2009.27.0660)

74 Imai Y, Taketani T, Maemura K, Takeda N, Harada T, Nojiri T, Kawanami D, Monzen K, Hayashi D, Murakawa Y et al. Genetic analysis in a patient with recurrent cardiac myxoma and endocrinopathy. Circulation Journal 200569 994-995. (doi:10.1253/circj.69.994)

75 Zawadzki KM \& Taylor SS. cAMP-dependent protein kinase regulatory subunit type II $\beta$ : active site mutations define an isoform-specific network for allosteric signaling by cAMP. Journal of Biological Chemistry 2004279 7029-7036. (doi:10.1074/jbc.M310804200)

76 Cazabat L, Ragazzon B, Groussin L \& Bertherat J. PRKAR1A mutations in primary pigmented nodular adrenocortical disease. Pituitary 20069 211-219. (doi:10.1007/s11102-006-0266-1) 
77 Stratakis CA, Carney JA, Lin JP, Papanicolaou DA, Karl M, Kastner DL, Pras E \& Chrousos GP. Carney complex, a familial multiple neoplasia and lentiginosis syndrome. Analysis of 11 kindreds and linkage to the short arm of chromosome 2. Journal of Clinical Investigation 199697 699-705. (doi:10.1172/JCI118467)

78 Horvath A, Bertherat J, Groussin L, Guillaud-Bataille M, Tsang K, Cazabat L, Libe R, Remmers E, Rene-Corail F, Faucz FR et al. Mutations and polymorphisms in the gene encoding regulatory subunit type 1- $\alpha$ of protein kinase A (PRKAR1A): an update. Human Mutation 201031 369-379. (doi:10.1002/humu.21178)

79 Kirschner LS, Sandrini F, Monbo J, Lin JP, Carney JA \& Stratakis CA. Genetic heterogeneity and spectrum of mutations of the PRKAR1A gene in patients with the carney complex. Human Molecular Genetics 20009 3037-3046. (doi:10.1093/hmg/9.20.3037)

80 Horvath A, Bossis I, Giatzakis C, Levine E, Weinberg F, Meoli E, Robinson-White A, Siegel J, Soni P, Groussin L et al. Large deletions of the PRKAR1A gene in Carney complex. Clinical Cancer Research $2008 \mathbf{1 4}$ 388-395. (doi:10.1158/1078-0432.CCR-07-1155)

81 Groussin L, Horvath A, Jullian E, Boikos S, Rene-Corail F, Lefebvre H, Cephise-Velayoudom FL, Vantyghem MC, Chanson P, Conte-Devolx B et al. A PRKAR1A mutation associated with primary pigmented nodular adrenocortical disease in 12 kindreds. Journal of Clinical Endocrinology and Metabolism 200691 1943-1949. (doi:10.1210/jc. 2005-2708)

82 Matyakhina L, Pack S, Kirschner LS, Pak E, Mannan P, Jaikumar J, Taymans SE, Sandrini F, Carney JA \& Stratakis CA. Chromosome 2 (2p16) abnormalities in Carney complex tumours. Journal of Medical Genetics 200340 268-277. (doi:10.1136/jmg.40.4.268)

83 Beuschlein F, Fassnacht M, Assie G, Calebiro D, Stratakis CA, Osswald A, Ronchi CL, Wieland T, Sbiera S, Faucz FR et al. Constitutive activation of PKA catalytic subunit in adrenal Cushing's syndrome. New England Journal of Medicine 2014370 1019-1028. (doi:10.1056/NEJMoa1310359)

84 Forlino A, Vetro A, Garavelli L, Ciccone R, London E, Stratakis CA \& Zuffardi O. PRKACB and Carney complex. New England Journal of Medicine 2014370 1065-1067. (doi:10.1056/NEJMc1309730)

85 Maillard JC. N-terminal capping propensities of the D-helix modulate the allosteric activation of the Escherichia coli cAMP receptor protein. Journal of Biological Chemistry 2012287 39402-39411. (doi:10.1074/jbc. M112.404806)
86 Groussin L, Kirschner LS, Vincent-Dejean C, Perlemoine K, Jullian E, Delemer B, Zacharieva S, Pignatelli D, Carney JA, Luton JP et al. Molecular analysis of the cyclic AMP-dependent protein kinase A (PKA) regulatory subunit $1 \mathrm{~A}$ (PRKAR1A) gene in patients with Carney complex and primary pigmented nodular adrenocortical disease (PPNAD) reveals novel mutations and clues for pathophysiology: augmented PKA signaling is associated with adrenal tumorigenesis in PPNAD. American Journal of Human Genetics 200271 1433-1442. (doi:10.1086/344579)

87 Meoli E, Bossis I, Cazabat L, Mavrakis M, Horvath A, Stergiopoulos S, Shiferaw ML, Fumey G, Perlemoine K, Muchow M et al. Protein kinase A effects of an expressed PRKAR1A mutation associated with aggressive tumors. Cancer Research 200868 3133-3141. (doi:10.1158/0008-5472. CAN-08-0064)

88 Greene EL, Horvath AD, Nesterova M, Giatzakis C, Bossis I \& Stratakis CA. In vitro functional studies of naturally occurring pathogenic PRKAR1A mutations that are not subject to nonsense mRNA decay. Human Mutation 200829 633-639. (doi:10.1002/humu. 20688)

89 Patronas Y, Horvath A, Greene E, Tsang K, Bimpaki E, Haran M, Nesterova M \& Stratakis CA. In vitro studies of novel PRKAR1A mutants that extend the predicted RIalpha protein sequence into the $3^{\prime}$-untranslated open reading frame: proteasomal degradation leads to RI $\alpha$ haploinsufficiency and Carney complex. Journal of Clinical Endocrinology and Metabolism 201297 E496-E502. (doi:10.1210/jc. 2011-2220)

90 Kirschner LS, Kusewitt DF, Matyakhina L, Towns WH II, Carney JA, Westphal H \& Stratakis CA. A mouse model for the Carney complex tumor syndrome develops neoplasia in cyclic AMP-responsive tissues. Cancer Research 200565 4506-4514. (doi:10.1158/0008-5472. CAN-05-0580)

91 Griffin KJ, Kirschner LS, Matyakhina L, Stergiopoulos SG, RobinsonWhite A, Lenherr SM, Weinberg FD, Claflin ES, Batista D, Bourdeau I et al. A transgenic mouse bearing an antisense construct of regulatory subunit type $1 \mathrm{~A}$ of protein kinase A develops endocrine and other tumours: comparison with Carney complex and other PRKAR1A induced lesions. Journal of Medical Genetics 200441 923-931. (doi:10.1136/jmg.2004.028043)

Received 22 February 2015

Revised version received 17 June 2015

Accepted 29 June 2015 